\title{
READING CULTURE IN POSTMODERN NARRATIVES
}

\section{Dr. Rajesh K Bharvad}

\section{ABSTRACT}

Postmodernism evolve from various cultural contexts and it is not independent of cultures but rather a direct representation of cultures. It is pertinent to note that all the narrative strategies in postmodern literature represent the cultural changes. In other words, fragmentation in postmodern literature is nothing but a reflection of fragmented culture. With its widespread influence, postmodern narrative strategies have been adapted in various cultures and locations. The fiction becomes an amalgamation of plural narrative patterns that correspondingly work to inscribe and dismantle the existing fundamentals. There are no fixed criteria to assign specific boundaries among various narrative strategies; they intersect each other indispensably.

Subversion of the metanarratives has led to pluralism and multiplicity, and it creates an environment of polyphony in the postmodern novel. The postmodern problem with metanarratives creates a natural scope for multiple narrative patterns in the fiction. In other words, all the strategies are parts of the postmodern plurality, and they inescapably rely on each other. For instance, in a magic realist text, apart from having magic realism as a key narrative strategy, other narrative strategies such as parodical inversions, playfulness, Bakhtinian carnivalesque, and postmodern historiography also coexist in the culture of pluralism. Hence, the research paper investigates how narrative strategies in postmodern literature are foregrounded in various cultural contexts, and their meanings exist in the cultures itself.

Keywords: Postmodernism, Culture, Parody, Historiography, and Narrative Strategies 
Postmodern narrative strategies evolved out of postmodern philosophical radicalism, which challenge the conventional metanarratives, carry out the functions of postmodern plurality and multiplicity. This directly results into the subversive nature of postmodern narrative strategies. Despite having the same philosophical and intellectual background, they are culture and location specific. For instance, magic realism, which developed in Latin America, is widely utilized by the writers from different locations. The narrative patterns of magic realism remain the same, but their functions and purposes change from one place to another. Magic realisms of Marquez, Angela Carter and Salman Rushdie have no similarities in terms of application. Magic realism of Marquez has been deeply rooted in the culture and history of Latin America and cannot be compared to magic realism of different writers. His magic realism is rooted in a culture wherein magic is an essential part of their routine life and hence, magic and real are naturally treated as common elements. On the other hand, Angela Carter weaves feminist sentiments in magic realism and sets the magic in the hearts of cities. The writer deliberately dwindles the distinctions between the real and the magic by inventing magic in busy life of cities which itself symbolize rationality and realistic beliefs. Both the writers adapt magic realism as a postmodern narrative strategy to express the local and cultural contexts. It is also found in the case of Salman Rushdie who utilizes magic realism in Midnight's Children to narrate the colonial history of India. Whether one considers Marquez's One Hundred Years of Solitude, Carter's Nights at the Circus or Rushdie's Midnight's Children, one can fathom an invariable link with the local culture.

Postmodernism is not limited to any specific location or culture, and it is found in major locations in the world. Postmodern plurality and subversiveness allow the writers from various cultures to narrate their local stories. Postmodern subversiveness or 'doublevoicedness' can be attributed to postmodern deconstruction of the metanarratives. The roots lie in the postmodern questioning of both the entire branches of epistemology and ontology. Both the philosophical implications and cultural contextualization are inscribed in postmodern fictions. With the metanarratives deconstructed, as mentioned by Lyotard, mininarratives of the world occupy the space in the fiction. This is the reason why postmodern writers across the world have adopted postmodern narrative strategies, and they seek to deconstruct the metanarratives of all the forms. 
With pluralism as its core ideology, there can be no line of demarcation between narrative strategies in postmodern fiction. Postmodern multiplicity and plurality generates endless possibilities of narrative strategies to be utilized by the postmodern writers. The narrative strategies discussed in the five chapters are fewer of them that are employed in majority of postmodern fictions. There are endless other postmodern narrative strategies which are cultural and location specific. The discussed narrative strategies present a larger perspective of the narrative strategies, and writers across the globe utilize them differently in their works. In fact, the endlessness and pluralism of postmodernism cannot be taped into specific categories, and there can be endless variations of the discussed narrative strategies in the fictions. For instance, magic realism of Japan, Africa, Latin America, India, Canada, England, and the USA display different perspectives, and these variations of multiplicity cannot be captured in totality. The manner of presentation and cultural adoptions make them different from one another. Parodical inversion of the past works and history found in The French Lieutenant's Woman is different from the parodical inversions interleaved in Midnight's Children or The Satanic Verses by Salman Rushdie of India. In the same line, it is construed that there can be innumerable narrative patterns evolving in postmodern fictions. Even the writers from the same country or location utilize the same narrative strategy with multiple or different variations. John Barth's The Sot-Weed Factor and John Fowles' The French Lieutenant's Woman are parodical inversions of the past with different narrative patterns. Despite belonging to the same country, their adaptations of the postmodern narrative strategies are different in nature and purpose. Barth generally focuses in deconstructing mythology, and in his works, he reconstructs the mythical world in the context of the modern world. On the other hand, Fowles deals more with history and the works of art belonging to the past, which he attempts to deconstruct through parodical inversions. With this endless plurality and multiplicity, it becomes pertinent to identify the larger perspective of the narrative strategies in the context of postmodern fiction.

In the present work, postmodern narrative strategies are explored in the context of the fiction, but the impact of postmodern subversiveness is equally seen in other genres as well. If postmodern poetry is observed, the elements such as the postmodern spirit of 
questioning and subversion, parodical inversions of the past forms, questioning the conventional unities in genres, and negating the truth-value system of the modernists are found in the works of major postmodern poets. Postmodern poetry, too, while questioning the conventional boundaries and unties tends to assume the form of prose, critical essay, the philosophical passage, or anything that might question the conventional unities. Postmodern poets such as Susan Howe, Charles Bernstein, and Ted Berrigan question the conventional ways of representation in the form of poetry.

Postmodern poetry deals with the problem of linguistic indeterminacy posed by the wing of post-structuralism. While differentiating with the modernist conventions of poetry endorsed by Eliot and Pound, Jennifer Ashton mentions the postmodern problem pertaining to language:

Where, for example, the modernism of Eliot has been identified with the autonomy of the text (or what postmodernism calls the "closed" text) and the determinacy of its meaning, the postmodern text is "open" and its meaning is indeterminate. And where the participation of the reader was thought to be irrelevant to the text in modernism, it has become not just relevant but crucial to the text in postmodernism (1).

Ashton clearly narrates the postmodern tendency to narrate the linguistic indeterminacy wherein the modern closure is negated in favour of the postmodern multiplicity denying the fixities and the unities endlessly. In comparison of the modernist poetry, which espouses unity and organic quality in poetry, the postmodern poetry openly involves the reader's participation and flouts the norms of organic quality. The same phenomenon is found in the postmodern fiction, wherein, as Hutcheon calls, 'an enunciative act' takes place. The postmodern poetry, just like postmodern fiction, does not deny the continuation of the modernist tendencies. Both postmodern fiction and poetry continue the traditions of experimental writing, but their approach and treatment are different. It brings out the controversial question pertaining to the relationship between modernism and postmodernism. It has already been discussed that they share a common path, but their ways and approaches are certainly different. In other words, postmodern poetry, just like fiction, is both the continuation and negation of the modernist tradition. 
It should be noted that postmodernism is a cultural movement and both fiction and poetry represent the conditions of the respective cultures. The fragmented form, loss of unity and organism, the loss of center, and the deconstructed notions pertaining to ontology and epistemology are perpetually rooted in the postmodern culture. While referring to Berrigan's Sonnets, Huntsperger highlights the cultural contexts in the formal carnival of the postmodern poetry. He mentions, "In repeatedly assembling and reassembling units of language, Berrigan's work can also be said to register the repetitive, mechanized conditions of intellectual labor in postindustrial society. In this sense, The Sonnets simultaneously instantiate cultural production and encodes the conditions of production that exist within the social totality" (42). Berrigan's Sonnet takes the route of parodical references and his poems refer to the works of Shakespeare, Ashbery, Mayakovsky, and O'Hara. Huntsperger further says, "He (Berrigan) proceeds by blending his own work and that of other poets in such a way that the final product displays his own idiocultural encoding" (44-5).

The postmodern poets equally highlight the problem of representation; the poets depict the problem of reference and the subversion of formal unity in the postmodern poetry. Susan Howe's poetry can be an example of this phenomenon. A few lines from Nether John and John Harbinger (Howe 7) can illuminate this point.

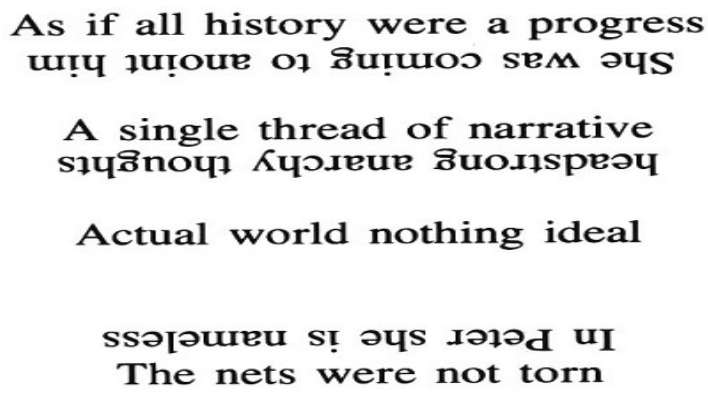

The Gospel did not grasp

The poem narrates the problem of representation in the postmodern poem. The writer, while attempting to suggest the postmodern problem of representation portray an inherent and perpetual indeterminacy in language and negates the idea of the final signified. Unlike the symbolic modern poems, the poem directly narrates the representational problem of language and form. 
The subversive tendencies to defy the conventional form of the poetry can be found in numerous postmodern poets. In an attempt to defy the conventional style of writing poetry, Charles Bernstein presents his poems in a prose-like manner. The writer presents his poem in the way that the binary between prose and poetry is deconstructed. He presents his poem Debris of Shock/Shock of Debris in the prose-like style. Some of the lines are as follows:

The debt that pataphysics owes to sophism

cannot be overstated. A missionary with a horse

gets saddlesores as easily as a politburo

functionary. But this makes a mishmash of overriding ethical

impasses. If the liar

is a Cretan I wouldn't trust him .... (109).

Despite having poetic appearance, the poem runs in simple sentences just like any other prose. Referring to the simple prose-like style of Bernstein, Lazer attempts to highlight the postmodern subversive spirit in his poems. He posits, "Bernstein's entire poetic output answers that question by embodying modes of writing and thinking that resist simple commodification and that undermine most forms of normalized, standardized 'communication'" (139). It is grasped that poetry, just like fiction, questions the final authority, becomes subversive, mixes genres to thwart unity and finality, and employs parody and irony to subvert the metanarratives.

Postmodern theatre also follows the same tradition of posing questions and subverting the unities and metanarratives. It opposes the modernist theatrical practices pertaining to absurdity. The postmodern wing of the theatrical world negates the nihilistic and apocalyptic tendencies found in the plays of Samuel Beckett and Eugene O'Neill. The postmodern playwrights also follow postmodern narrative strategies found in both poetry and fiction. The linguistic indeterminacy, intertextual or parodical references to the works of the past, negation of linear narrative patterns, dissolving, questioning, and subverting the conventional boundaries between tragedy and comedy, self-conscious 
and playful narrator, and multiplicity and plurality are found in the postmodern theatrical representations of the era. Postmodern playwrights such as Tom Stoppard, David Mamet, Sam Shepherd, and Eric Bogosian employ postmodern tactics of representation in their works. Just like historiographic metafiction, Tom Stoppard's metafictional plays, too, draw from various historical sources (artistic as well as social history), and narrate them through metatheatrical practices. His Rosencrantz and Guildenstern Are Dead is an example in which an alternative version of the two characters drawn from Shakespeare's Hamlet is found. The entire story of Hamlet is modified and presented from an altogether different point of view. The story becomes a parodical inversion of the original Hamlet. Postmodern theatre dwindles the conventional binaries between art and life, and theatrical world and the audience. The reader's participation seen in the postmodern novels is also noticed in postmodern drama wherein the actors and the audience work together to create a theatrical experience.

The postmodern question of authorship is visible in drama. Kerstin Schmidt, with reference to this authorship, highlights the perpetual problems of authorship and the problem of representation in drama. He posits:

Dramatic authorship and other constitutive features of drama invite, even call for a "postmodern" drama. In addition to the unstable notion of authorship, the dramatic concept of self and personal identity readily expresses postmodern concerns. As indeterminable as dramatic authorship, the fragmentation of the self is a given in drama by the actor character split (10).

Drama becomes a suitable form, in some ways, to highlight postmodern problems of representation. It allows the dramatists to both post questions in the written discourse and test their credibility during the theatrical performance. Kerstin Schmidt further states in this regard:

Drama and theater are particularly suited to raise questions about the relationship between text, discourse, and performance, about the transformation of fixed words on the page into an articulation on stage, about presence and representation, about the pluralized and fragmented self, about the role of 
spatiality, and about drama's own conditions and processes of existence-all of which are major postmodern concerns (11).

There are a number of postmodern works that propound and inscribe postmodern issues in them. Megan Terry in Keep Tightly Closed in a Cool Dry Place, and JeanClaude van Itallie in I'm Really Here and Almost Like Being present the postmodern problems of narration, and postmodern parodical inversions in their metatheatrical drama. Kerstin Schmidt highlights the elements of parodical inversions of the past. $\mathrm{He}$ suggests, "In most cases, the postmodern reverence for canonical texts and for popcultural works does by no means entail a simple mimetic representation of the quoted texts, but rather transforms them by subverting their authoritative status through parody and other strategies of differentiation and fragmentation" (36).

Just as postmodern poetry and drama, postmodern films, too, pose postmodern questions. Postmodern narrative tactics are perceived in numerous postmodern films. They, just like the other postmodern art forms, attempt to subvert conventional narrative framework of representation in cinema. One of the popular conventions 'suspension of disbelief' is either parodied or openly subverted in the films. Modern transparency, closed ends, modernist faith in the author, and accessibility to reality are either parodied or negated. Postmodern films, to reject the modernist unity, includes multiple genres and uses parody as a main tool to subvert the conventional forms of representation. The movies break away from the modernist linearity and cause-effect notions. Postmodern movies such as Blue Velvet, Pulp Fiction, Synecdoche, Ghost in the Shell, The Matrix Trilogy, Sex, Lies, and Videotape, Scary Movie, and Austin Powers are some of the popular examples of postmodern movies.

These movies present postmodernism in their narratorial tactics. Austin Powers is a parodical inversion of the popular Bond series. The movie parodies the spy genre popularized in the Bond series. It ironizes the glamorized heroism and sexual encounters, and it subverts them with the playfulness of the central hero. Similar is the case with Scary Movie in which multiple genres are parodically fused together. The movie while being intertextual refers to many historical and popular movies, and their characters. The attempt, however, is not to glamorize them, but to parodically subvert 
metanarratives and finality associated with the grandeur of the characters. The technique of self-referentiality or meta-fiction is also popular among the postmodern films. Monty Python and The Holy Grail, for instance, meta-fictionally reminds the viewer about its being unreal. Synecdoche, similarly, questions the conventional boundaries between reality and fiction. The movie breaks away with the conventional narrative patterns of linearity, and the story is presented haphazardly. Many critics notify the deconstruction of the conventional truth-value system and related metanarratives in the films. While referring to Blue Velvet, and Charlie and the Chocolate Factory, M. Keith Booker mentions:

Also closely related to the collapse of belief in totalizing systems is the demise of the tradition of Aristotelian logic, through which Western society had long defined itself via a series of polar oppositions, the central of which were Good versus Evil and Us versus Them—-both of which, in the Western tradition, ultimately amount to pretty much the same thing. Without such clear distinctions to rely on, postmodernist thought tends toward a radical relativism, in which no point of view can be maintained as absolutely superior to any other. The lack of any real message in films such as Blue Velvet and Charlie and the Chocolate Factory again comes into play here, as does the fact that so many aspects of the films don't really make sense from a logical perspective (xvi).

Just as postmodern fictions deconstruct the conventional metanarratives, films, too, deconstruct conventional metanarratives that have been dominant in western societies. There are endless examples that carry the postmodern tactics of representation.

The impact of postmodern tendencies in various forms of art is widely seen in major parts of the world. The questions pertaining to postmodernism must be posed, which itself only poses questions. One of the drawbacks noticed by the critics is that it merely poses questions and does not either seek answers or attempt to offer them. The subversiveness in postmodernism only subverts the existing metanarratives in the society, but does not offer any alternatives. Postmodernism, similarly, is blamed for playing endless language games of subversion with or without any purpose. The question that we have is whether this endless process of questioning or subversion lead 
to any conclusion, or will this process of posing questions lead to any conclusion and fruitful answers.

The postmodern viewpoint with respect to the blame is that it can never propose fixed and definite answers. The postmodern opposition to the metanarratives cannot allow the postmodernists to offer either solutions or answers, as it would lead to yet another metanarrative of different type. This forces the postmodernists to deal with the perpetual stance of posing questions. It must be understood that postmodernism allows mininarratives and pluralities based on individual relativism. In order to stop any narrative turning into a metanarrative, postmodernists continue to pose questions that might stall the possibilities of new metanarratives. Postmodernism has to be both critical and subversive as it intends to deconstruct center in any form. The true nature of postmodernism can only be revealed in this multiplicity and deconstruction of all the centers. The centers such as language, realism, history, patriarchy, and other fundamentals of the society have to be deconstructed, but any alternative center cannot be proposed as it will go against the grain of postmodernism. If postmodernism provides final answers, it will kill its own spirit of multiplicity, plurality, and endlessness. This is the reason why postmodernism never ceases to be problematic and becomes an enigma without solutions.

This endlessness, plurality and an enigma without a solution allow the writers to reach into endless horizons. The worth of postmodernism can be understood in its global acceptance and relevance. Modernism, with its elite nature, could only reach to the specific audiences only. Postmodernism, on the other hand, reaches to all the major parts of the world and various sections of the society. The worth of postmodernism, despite its resistance to the final solutions, cannot be questioned as its worth lies in the questioning itself. It can be seen in the fact that its plurality, endlessness, and deferral of meaning in language allow the writers to see and explore the world unseen hitherto. For instance, postmodern questioning and subverting of the boundaries between the conventional binaries such as fact/fiction, reality/fiction, true/false, history/fiction, dream/reality and life/death allows the writers to celebrate the magical world fused with Bakhtinian Carnivalesque. Postmodernism is appropriate when it declines final solutions 
as postmodern worlds and cultures do not possess them or in other words, they do not exist in postmodern culture. And it rejects this tendency to look for solutions in the world in which final solutions never existed. This is the reason why postmodernism proffers multiple and endless truths or solutions and rejects the modernist 'closure'.

Postmodernism, despite its widespread popularity, has faced questions pertaining to its existence and the end. Many critics have questioned the existence of postmodernism raising the doubts on its existence. Critics like Habermas consider postmodernism just as a continuation of modernism or the project of enlightenment. The existence of postmodernism can never be questioned as it is not merely an ideological position or stance, but the post-war culture that brings the postmodern enigma into existence. Postmodern culture is and will be invariably different from the previous culture. Post-war cultures of the west and the east have changed dramatically, and the need of postmodernism becomes inevitable as the metanarratives and conclusiveness of modernism become irrelevant not just in postmodern ideology, but in its core culture. It is a cultural need that makes postmodernism to be what it is. The postmodernists like Derrida, Foucault, Barthes, Rorty, Baudrillard, and Lyotard present their discourses that not only prepare the ground for postmodern pluralism but also identify the cultural change in the contemporary world. This shift in cultures becomes the cause of postmodern existence. After having seen the final idea, the truth, and the metanarrative to cater the needs of the entire world, the postmodern culture ceases to believe in the finalities and offers no such alternatives, but revels in the vortex of endlessness.

There is one more doubt that has been raised by many critics regarding the end of postmodernism. Has postmodernism, just like the previous cultural changes and various ages, outlived its time? Josh Toth has already suggested the end of postmodernism. He points out that there is a shift in contemporary narrative that is marked by the growing dominance of a type of neo-realism, and by an increased theoretical interest in the issues of community and ethical responsibility. He further adds that there is a shift in stylistic privilege as the ostentatious works of postmodern metafiction are rejected in favor of more grounded or responsible works of neo-realism. The subversive and nihilistic approaches of postmodernism have been rejected in favor of what can be 
called as political commitment and responsibility. Toth states, "It is possible to refer to this epistemological reconfiguration after postmodernism-just as it is possible to refer to the episteme after modernism, as a period of mourning, a period in which we struggle to get over (i.e., conjure/exorcise) that which has passed, or that which is past" (22).

The British cultural critic Alan Kirby also suggests the death of postmodernism. He opines, "There are people who have essentially asserted that for a while we believed in postmodern ideas, but not anymore, and from now on we're going to believe in critical realism" (The Death of Postmodernism). He also highlights the new beginning of an era. He posits:

Its successor, which I will call pseudo-modernism, makes the individual's action the necessary condition of the cultural product. Pseudo-modernism includes all television or radio programmes or parts of programmes, all 'texts', whose content and dynamics are invented or directed by the participating viewer or listener (although these latter terms, with their passivity and emphasis on reception, are obsolete: whatever a telephoning Big Brothervoter or a telephoning 6-0-6 football fan are doing, they are not simply viewing or listening) (The Death of Postmodernism).

He suggests that the new and rapid development of the virtual world of internet generates new possibilities in the culture. The growing dependence on the internet has made people behave and think differently. She further defines the term as 'pseudomodernism':

The pseudo-modern cultural phenomenon par excellence is the internet. Its central act is that of the individual clicking on his/her mouse to move through pages in a way which cannot be duplicated, inventing a pathway through cultural products which has never existed before and never will again. This is a far more intense engagement with the cultural process than anything literature can offer, and gives the undeniable sense (or illusion) of the individual controlling, managing, running, making up his/her involvement with the cultural product (The Death of Postmodernism). 
Many critics have termed the end of postmodernism with the fall of the World Trade Center. Neil Brooks and Josh Toth opines, "if postmodernism became terminally ill sometime in the late-eighties and early-nineties, it was buried once and for in the rubble of the World Trade Center" (3). They also mention the role of computers and digital media as key forces in the contemporary society. They point out this change:

As computers penetrate and inform everyday practices in virtually all areas of society and culture, performance acquires a more active role in the production of texts as well as buildings than was previously the case with print media, creating possibilities for dynamic physical and textual environments that change in response to user intervention and real-time data flows (101).

The demise of postmodernism, which itself is opposed to the end and closure, is not likely to be seen in the near future. Postmodern pluralism and its nature of inclusiveness encompass a wide range of possibilities to adapt the new cultural changes. It is, however, pertinent to acknowledge the possibility of demise at a certain point of time. In the present context, the relevance of postmodernism does not seem to be waning. Postmodern plurality and multiplicity holds its ground in the changing cultural perspectives. Postmodernism achieves a rare feat while transgressing cultural boundaries around the world to create its stronghold as a movement. Its opposition to all the conventional metanarratives and fixed solutions allows it to be popular among all the sections of the society, be it feminists, black writers, white writers or even writers from different locations and cultures across the world. The debate regarding the demise of the postmodern is still controversial and not universally accepted, since it is still alive in the world of contemporary academia. Further, postmodern fictions continue to evolve even in the present culture; the recent postmodern novels such as Catch-22 by Joseph Heller, Breakfast of Champions by Kurt Vonnegut, City of Dark Magic by Magnus Flyte, 10:01 by Lance Olsen, and And Then There Was No One by Gilbert Adair are the examples that narrate the postmodern spirit of plurality and multiplicity in them.

Postmodernism, unlike modernism, does not offer a fixed methodology or a fixed narrative pattern. The core self of postmodernism lies in the idea of pluralism and the spirit of interrogations. In fact, postmodernism cannot be thought in the perspective of 
its beginning and an end, since the spirit of interrogation and pluralism was found before even modernism came into existence, and hence, it is bound to be there perpetually. In other words, postmodernism is not an invention, which might become irrelevant in the changing times, but a discovery, which was there in the past and is likely to be even in future. It is an idea that consists of the spirit of pluralism and subversiveness bound to interrogate or question the metanarratives. This postmodern spirit, which seems to possess the quality of timelessness, can be seen in both present and future cultures and fictions of the world. The spirit is and will have far-reaching influence on the future cultural or literary movements. 


\title{
Works Cited
}

Ashton, Jennifer. From Modernism to Postmodernism: American Poetry and Theory in the Twentieth Century. Cambridge, UK: Cambridge UP, 2005.

Bernstein, Charles. Dark City. Los Angeles: Sun \& Moon, 1994.

Booker, M. Keith. Postmodern Hollywood: What's New in Film and Why It Makes Us Feel so Strange. London: Praeger, 2007.

Brooks, Neil, and Josh Toth, eds. The Mourning After: Attending the Wake of Postmodernism. Amsterdam: Rodopi, 2007.

Huntsperger, David. Procedural Form in Postmodern American Poetry: Berrigan, Antin, Silliman, and Hejinian. New York: Palgrave Macmillan, 2010.

Howe, Susan. The Nonconformist's Memorial: Poems. New York: New Directions, 1993.

Kyrby, Alan. "The Death of Postmodernism and Beyond." Philosophy Now: A Magazine of Ideas. Vol. 58. London: 2006. N.pag. Web. 22 June 2015.

Lazer, Hank. Opposing Poetries / Readings. Evanston III.: Northwestern U, 1996.

Schmidt, Kerstin. The Theater of Transformation: Postmodernism in American Drama. Amsterdam: Rodopi, 2005.

Toth, Josh. The Passing of Postmodernism: A Spectroanalysis of the Contemporary. Albany: State U of New York, 2010.

\author{
Dr. Rajesh K Bharvad \\ Assistant Professor \\ Department of English \\ Faculty of Arts \\ The Maharaja Sayajirao University of Baroda, Vadodara \\ Email: rajeshb4390@gmail.com
}

